Research Article

\title{
Epidemiological profile of Cancer patients in Surgery ward of a tertiary teaching Hospital in the Vindhya region with special reference to high proportion of Carcinoma Gall Bladder
}

\author{
Shukla $\mathbf{D}^{1}$, Patel VK ${ }^{2}$, Chhari $\mathrm{AS}^{3,}$ Dubey $\mathrm{CS}^{4}$, Garg $\mathrm{RK}^{5}$, Singh $\mathrm{AP}^{6}$, Bais $\mathrm{PS}^{7}$, Gaharwar $\mathrm{APS}^{8}$ \\ ${ }^{1}$ Dr Dhanwantari Shukla, Resident, ${ }^{2}$ Dr Vishnu Kumar Patel, Assistant Professor, ${ }^{3}$ Dr Akash Singh Chhari, Resident, \\ ${ }^{4}$ Dr Chandrashekhar Dubey, Resident, ${ }^{5}$ Dr Rishi Kumar Garg, Resident, ${ }^{6}$ Dr AP Singh, Resident ${ }^{7}$ Dr PS Bais, Resident, \\ ${ }^{8}$ Dr APS Gaharwar, Professor. All are affiliated with Department of Surgery, S. S. Medical College, Rewa, MP, India.
}

Address for Correspondence- Dr. Dhanwantari Shukla, Resident, Department of Surgery, S. S. Medical College, Rewa MP, India.

\begin{abstract}
WHO estimates that by 2030, the incidence of Cancer will increase by $68 \%$ as compared to 2012. This study evaluates epidemiological profile of Cancer in the Vindhya region. Design: Combination of retrospective and prospective study. Methodology: All Cancer patients admitted in Surgery Ward of S.S. Medical College, Rewa between 2010-2014 were included in the study. Data regarding age, gender, religion, socio-economic status, residence, dietary habits, addiction and site of Cancer as well as mortality pattern of Cancer was tabulate, analyzed and compared. Results: 1186 cases were included in this study, 50.25\% were males and $49.75 \%$ were females. Most common age groups were middle age group (35-64 years) and geriatric (57.59\% and 30.86\%). 95.78\% were Hindus and 4.22\% were Muslims. 70.40\% were BPL, $29.60 \%$ were APL. $67.20 \%$ belonged to rural areas, $32.80 \%$ were from urban areas. $75.89 \%$ were vegetarians, $24.11 \%$ were non-vegetarians. $25.97 \%$ were addicted to tobacco alone, $1.52 \%$ to alcohol alone and $18.63 \%$ to both tobacco and alcohol. Overall, Breast Cancer was the most prevalent Cancer (19.06\%), followed by Cancer Gall Bladder (10.55\%). Among males, Colorectal Cancer was the commonest $(11.24 \%)$, Gall Bladder was the $4^{\text {th }}$ commonest $(8.22 \%)$. Among females, Breast was the commonest $(37.12 \%)$ and Gall Bladder was the $2^{\text {nd }}$ commonest $(12.88 \%)$. Gall Bladder cancer was the commonest (13.93\%) in geriatric age group. Gall Bladder cancer was the commonest cause of Cancer deaths overall. Conclusion: Cancer of Gall bladder has emerged as a major cause of morbidity and mortality in this study.
\end{abstract}

Key words: Cancer, Gall bladder, Epidemiological, Mortality.

\section{Introduction}

Neoplasm, which can be defined as excessive and unregulated proliferation of cells independent of physiological growth-stimulatory stimuli is said to have become malignant when it attains a property of invading and destroying adjacent structures and spreading to distant sites (metastasize) to cause death [2]. Cancer has a 5 millennia old history but it continues to haunt human societies and perplex clinicians with its wide variety of clinical course and often fatal outcome. Cancer is associated with a tremendous socio-economic as well as psychological burden. The annual incidence of Cancer is 14 million and it kills 8.2 million people annually [3]. 1 in every 8 deaths is due to Cancer [4]. More than a million Indians are diagnosed with Cancer

Manuscript Received: $16^{\text {th }}$ November 2015

Reviewed: $26^{\text {th }}$ November 2015

Author Corrected: $17^{\text {th }}$ December 2015

Accepted for Publication: 30 ${ }^{\text {th }}$ December 2015 each year while 6-7 lakhs of them lose their lives annually. The incidence and mortality both have increased by about $50 \%$ over past 2 decades [5]. The greatest strides in the field of Oncology have been made by epidemiological studies which helped in identifying the carcinogenic factors subsequently leading to discovery of the therapeutic modalities. $80-90 \%$ of all Cancers are believed to arise from environmental and lifestyle risk factors [6]. The world of cancer management has seen a revolutionary change over the past century. From the days of clinical diagnosis, we have come to the era of tissue diagnosis and conventional imaging modalities like X-ray and USG are being supplemented with advanced imaging techniques like CT, MRI, PET and other radioisotopelabeled studies. Cancer therapeutics involves multiple 


\section{Research Article}

disciplines like Surgery, Chemotherapy, Radiotherapy and Immunotherapy.

Cancer of Gall Bladder is often asymptomatic or vaguely symptomatic, prompting patients to present at a stage where curative treatment is no more an option. Gall bladder cancer is the commonest biliary tract malignancy and is particularly common in North and Central India [13].

This study describes the epidemiological profile of cancer patients admitted in a tertiary teaching hospital in the Vindhya region concerning various demographic parameters and the organs involved and highlight the high prevalence and mortality of cancer of Gall bladder.

\section{Aims and objectives}

1. To know the overall incidence of malignancy and its distribution in relation to age, sex, occupation, religion, socio-economic status, residence, dietary habits, addiction and the stage of disease in which the diagnosis was made.

2. To study the change in the trend of cancer incidence and mortality over a study period of 5 years.
3. To study mortality in various malignancies

4. To highlight the high prevalence and mortality of cancer of Gall Bladder

\section{Materials and Methods}

This study was carried out on 1186 patients of Cancer admitted in the surgical ward of S.S. Medical College, Rewa between $1^{\text {st }}$ January 2010 to $31^{\text {st }}$ December 2014.

Records of cancer patients admitted between $1^{\text {st }}$ Jan 2010-31 $1^{\text {st }}$ May 2014 were obtained from Central Registration of Surgery Department and patients diagnosed with cancer from $1^{\text {st }}$ June 2014-31 $1^{\text {st }}$ December 2014 were examined individually.

Age, gender, residence, occupation, addiction, socioeconomic status, dietary habits, presenting complaints, history, examination, investigation, treatment and outcome were recorded meticulously in proforma/ master chart for systematic tabulation, observation and statistical analysis.

\section{Results}

Table-1: Distribution of patients according to age \& gender $(\mathbf{n}=1186)$

\begin{tabular}{|l|l|l|l|l|l|l|}
\hline \multirow{2}{*}{ Age (years) } & \multicolumn{2}{|l|}{ Male } & Female & \multicolumn{2}{l|}{ Total } \\
\cline { 2 - 7 } & Number & $\%$ & Number & $\%$ & Number & $\%$ \\
\hline $0-14$ & 2 & 0.17 & 4 & 0.34 & 6 & 0.50 \\
\hline $15-34$ & 63 & 5.32 & 68 & 5.73 & 131 & 11.05 \\
\hline $35-64$ & 300 & 25.30 & 383 & 32.29 & 683 & 57.59 \\
\hline $65+$ & 231 & 19.48 & 135 & 11.38 & 366 & 30.86 \\
\hline Total & 596 & 50.25 & 590 & 49.75 & 1186 & 100.00 \\
\hline
\end{tabular}

It is evident from the Table 1 that incidence of cancer was almost equal in males $(50.25 \%)$ and females (49.75\%). Maximum (57.59\%) of the patients were from the middle age group (35-64 years) in both genders.

The proportion in geriatric age group (65+ years) was $30.86 \%$ and was the $2^{\text {nd }}$ commonest age group in both genders. The proportion of patients in young adults (15-34 years) was $11.05 \%$ and that of pediatric population (0-14 years) was $0.50 \%$.

It is evident from the Table 2 that $95.78 \%$ of the patients were Hindus, $4.22 \%$ were Muslims. About two-thirds (67.20\%) belonged to rural areas, about one-third (32.80\%) belonged to urban areas.

The percentage of BPL (below poverty line) patients was $70.40 \%$, rest $29.60 \%$ were APL (Above Poverty Line). About three-fourths $(75.89 \%)$ patients were vegetarians, one-fourths $(24.11 \%)$ were non-vegetarians. $25.97 \%$ patients were addicted to tobacco alone, $1.52 \%$ to alcohol alone, $18.63 \%$ to both tobacco and alcohol, $53.88 \%$ were not addicted 


\section{Research Article}

Table-2: Distribution of patients according to religion, residence, socio-economic status, dietary habits and addiction $(\mathbf{n}=\mathbf{1 1 8 6})$.

\begin{tabular}{|c|c|c|c|c|}
\hline Sr. No. & \multicolumn{2}{|l|}{ Characteristic } & \multirow{2}{*}{$\begin{array}{l}\text { Number } \\
1136\end{array}$} & \multirow{2}{*}{$\begin{array}{l}\text { Percentage } \\
95.78 \\
\end{array}$} \\
\hline \multirow{3}{*}{1} & \multirow{3}{*}{ Religion } & Hindus & & \\
\hline & & Muslims & 50 & 4.22 \\
\hline & & Total & 1186 & 100.00 \\
\hline \multirow{3}{*}{2} & \multirow{3}{*}{ Residence } & Urban & 389 & 32.80 \\
\hline & & Rural & 797 & 67.20 \\
\hline & & Total & 1186 & 100.00 \\
\hline \multirow{3}{*}{3} & \multirow{3}{*}{ Socio-economic status } & APL & 351 & 29.60 \\
\hline & & BPL & 835 & 70.40 \\
\hline & & Total & 1186 & 100.00 \\
\hline \multirow[t]{3}{*}{4} & \multirow{3}{*}{ Dietary habits } & Vegetarians & 900 & 75.89 \\
\hline & & Non-vegetarians & 286 & 24.11 \\
\hline & & Total & 1186 & 100.00 \\
\hline \multirow{5}{*}{5} & \multirow{5}{*}{ Addiction } & Tobacco alone & 308 & 25.97 \\
\hline & & Alcohol Alone & 18 & 1.52 \\
\hline & & Tobacco + Alcohol & 221 & 18.63 \\
\hline & & No addiction & 639 & 53.88 \\
\hline & & Total & 1186 & 100.00 \\
\hline
\end{tabular}

Table-3: Gender wise distribution of 10 commonest Cancers $(\mathbf{n}=1186)$.

\begin{tabular}{|c|c|c|c|c|c|}
\hline \multicolumn{3}{|l|}{ Males } & \multicolumn{3}{|l|}{ Females } \\
\hline Site & No. & Percentage & Site & No. & Percentage \\
\hline Colorectal & 67 & 11.24 & Breast & 219 & 37.12 \\
\hline Prostate & 61 & 10.24 & Gall Bladder & 76 & 12.88 \\
\hline Penis & 61 & 10.24 & Colorectal & 43 & 7.28 \\
\hline Gall Bladder & 49 & 8.22 & Cervix & 39 & 6.61 \\
\hline Stomach & 45 & 7.55 & Stomach & 33 & 5.59 \\
\hline Skin+Soft tissue & 42 & 7.05 & Cholangiocarcinoma & 24 & 4.06 \\
\hline Periampullary & 41 & 6.88 & Skin+Soft tissue & 22 & 3.73 \\
\hline Oral cavity & 41 & 6.88 & Periampullary & 19 & 3.22 \\
\hline Hepatocellular & 27 & 4.53 & Hepatocellular & 19 & 3.22 \\
\hline Urinary Bladder & 24 & 4.03 & Ovary & 19 & 3.22 \\
\hline 10 commonest & 458 & 76.84 & 10 commonest & 513 & 86.94 \\
\hline Others & 138 & 23.16 & Others & 77 & 13.06 \\
\hline Total & 596 & 100.00 & Total & 590 & 100.00 \\
\hline
\end{tabular}

It is evident from the table that among males, the 10 commonest cancers were those of Colorectum (11.24\%), Prostate $(10.24 \%)$, Penis $(10.24 \%)$, Gall Bladder $(8.22 \%)$, stomach $(7.55 \%)$, skin + soft tissue $(7.05 \%)$, periampullary $(6.88 \%)$, oral cavity $(6.88 \%)$, Hepatocellular $(4.53 \%)$ and Urinary Bladder $(4.03 \%)$. Among females, the 10 commonest cancers were those of Breast (37.12\%), Gall Bladder (12.88\%), Colorectum (7.28\%), cervix (6.61\%), stomach (5.59\%), cholangio (4.06\%), skin+soft tissue (3.73\%), Periampullary (3.22\%), Hepatocellular (3.22\%) and ovary (3.22\%). 
Research Article

Table-4: Age wise distribution of 10 commonest Cancers $(\mathbf{n}=1186)$.

\begin{tabular}{|c|c|c|c|c|c|c|c|c|c|c|c|}
\hline \multicolumn{3}{|l|}{ Pediatric } & \multicolumn{3}{|l|}{ Young adult } & \multicolumn{3}{|l|}{ Middle } & \multicolumn{3}{|l|}{ Geriatric } \\
\hline Site & No. & $\%$ & Site & No. & $\%$ & Site & No. & $\%$ & Site & No. & $\%$ \\
\hline Kidney & 4 & 66.66 & Colorectal & 19 & 14.51 & Breast & 170 & 24.89 & Gall Bladder & 51 & 13.93 \\
\hline Colorectal & 1 & 16.67 & Breast & 18 & 13.74 & $\begin{array}{l}\text { Gall } \\
\text { Bladder }\end{array}$ & 64 & 9.37 & Prostate & 45 & 12.31 \\
\hline \multirow{10}{*}{$\begin{array}{l}\text { Retroperiton } \\
\text { eal }\end{array}$} & 1 & 16.67 & Skin & 14 & 10.69 & Colorectal & 56 & 8.20 & Breast & 38 & 10.38 \\
\hline & & & Testis & 11 & 8.40 & Stomach & 42 & 6.15 & Colorectal & 34 & 9.29 \\
\hline & & & $\begin{array}{l}\text { Gall } \\
\text { Bladder }\end{array}$ & 10 & 7.63 & $\begin{array}{l}\text { Periampulla } \\
\text { ry }\end{array}$ & 41 & 6.00 & Stomach & 32 & 8.74 \\
\hline & & & $\mathrm{CNS}$ & 8 & 6.11 & Penis & 33 & 4.83 & Penis & 26 & 7.10 \\
\hline & & & $\begin{array}{l}\text { Hepatocellu } \\
\text { lar }\end{array}$ & 6 & 4.58 & Cervix & 30 & 4.39 & Skin & 21 & 5.74 \\
\hline & & & Oral cavity & 6 & 4.58 & Oral cavity & 30 & 4.39 & $\begin{array}{l}\text { Urinary } \\
\text { Bladder }\end{array}$ & 17 & 4.64 \\
\hline & & & Bone & 4 & 3.05 & Skin & 29 & 4.25 & $\begin{array}{l}\text { Periampullar } \\
\text { y }\end{array}$ & 16 & 4.37 \\
\hline & & & Stomach & 4 & 3.05 & $\begin{array}{l}\text { Hepatocellu } \\
\text { lar }\end{array}$ & 29 & 4.25 & Esophagus & 16 & 4.37 \\
\hline & & & Lymphoma & 4 & 3.05 & & & & & & \\
\hline & & & Cervix & 4 & 3.05 & & & & & & \\
\hline $\begin{array}{l}10 \\
\text { Commonest }\end{array}$ & 6 & 100 & $\begin{array}{l}10 \\
\text { commonest }\end{array}$ & 108 & 82.44 & $\begin{array}{l}10 \\
\text { commonest }\end{array}$ & 524 & 76.72 & $\begin{array}{l}10 \\
\text { commonest }\end{array}$ & 296 & 80.87 \\
\hline Others & 0 & 0 & Others & 23 & 17.56 & Others & 159 & 23.28 & Others & 70 & 19.13 \\
\hline Total & 6 & 100 & Total & 131 & 100 & Total & 683 & 100 & Total & 366 & 100 \\
\hline
\end{tabular}

It is evident from the Table 4 that in the pediatric age group, Wilm's tumour of kidney was the commonest cancer accounting for $66.67 \%$ of cases and was followed by Colorectum and Retroperitonel sarcoma (16.67\% each). In the young adult group, the 10 commonest cancers were Colorectum $(14.51 \%)$, Breast $(13.74 \%)$, Skin + soft tissue $(10.69 \%)$, testis $(8.40 \%)$, Gall Bladder (7.63\%), CNS (6.11\%), Hepatocellular Carcinoma (4.58\%),

Oral cavity (4.58\%), Bone (3.05\%), Stomach (3.05\%), Lymphoma (3.05\%) and Cervix (3.05\%). In the middle age group, the 10 commonest Cancers were Breast (24.89\%), Gall Bladder (9.37\%), Colorectum (8.20\%), Stomach (6.15\%), Periampullary (6.00\%), Penis (4.83\%), Cervix (4.39\%), Oral cavity (4.39\%), Skin+soft tissue (4.25\%) and HCC (4.25\%). In the geriatric age group, the 10 commonest Cancers were Gall Bladder (13.93\%), Prostate (12.31\%), Breast (10.38\%), Colorectum (9.29\%), Stomach (8.74\%), Penis (7.10\%), Skin+soft tissue (5.74\%), Urinary Bladder (4.64\%), Periampullary (4.37\%) and Esophagus (4.37\%).

It is evident from Table 5 that 218 i.e. $18.38 \%$ of patients had distant metastasis at the initial presentation. 21 patients presented with Liver 2ndaries without detected primary lesion. 58 out of 125 i.e. $46.40 \%$ of patients of Cancer Gall Bladder presented with metastasis making it the Cancer with the highest no. of cases with metes at the initial presentation. 
Research Article

Table-5: Cancers with maximum number and proportion of metastasis at presentation $(\mathrm{n}=1186)$.

\begin{tabular}{|l|l|l|l|}
\hline Site & Total no. of cases & Presented with metastasis & Percentage \\
\hline Gall Bladder & 125 & 58 & $46.40 \%$ \\
\hline Cervix & 39 & 24 & $61.53 \%$ \\
\hline Liver 2 ${ }^{\text {ndaries }}$ Primary unknown & 21 & 21 & $100.00 \%$ \\
\hline Breast & 226 & 19 & $8.41 \%$ \\
\hline Colorectum & 110 & 17 & $15.45 \%$ \\
\hline Stomach & 78 & 10 & $12.82 \%$ \\
\hline Prostate & 61 & 8 & $13.11 \%$ \\
\hline Ovary & 19 & 8 & $42.10 \%$ \\
\hline Testis & 18 & 8 & $44.44 \%$ \\
\hline Hepatocellular Carcinoma & 46 & 8 & $17.39 \%$ \\
\hline 10 commonest & 743 & 181 & $24.36 \%$ \\
\hline Others & 443 & 37 & $8.35 \%$ \\
\hline Total & 1186 & 218 & $18.38 \%$ \\
\hline
\end{tabular}

Table-6: Distribution of Mortality of patients according to age \& gender (n=91).

\begin{tabular}{|l|l|l|l|}
\hline Sl. No. & Age (years) & Number & \% \\
\hline \multirow{4}{*}{1} & $0-14$ & 0 & 0.00 \\
\cline { 2 - 4 } & $15-34$ & 10 & 10.99 \\
\cline { 2 - 4 } & $35-64$ & 49 & 53.85 \\
\cline { 2 - 4 } & $65+$ & 32 & 35.16 \\
\cline { 2 - 4 } & Total & 91 & 100.00 \\
\hline \multirow{3}{*}{2} & Gender & Number & \% \\
\cline { 2 - 4 } & Male & 56 & 61.54 \\
\cline { 2 - 4 } & Female & 35 & 38.46 \\
\cline { 2 - 4 } & Total & 91 & 100.00 \\
\hline
\end{tabular}

It is evident from Table 6 that maximum deaths occurred in the middle age group (53.85\%) followed by geriatric age group $(35.16 \%)$ and young adults $(10.99 \%)$. There was no death among the pediatric patients. $61.54 \%$ of the deaths occurred among male patients and $38.46 \%$ among female patients.

Table-7: Distribution of 10 commonest causes of mortality $(n=91)$.

\begin{tabular}{|l|l|l|}
\hline \multirow{2}{*}{ Site of Cancer } & Total & Percent \\
\cline { 2 - 3 } & Number & 14.29 \\
\hline Gall Bladder & 13 & 13.17 \\
\hline Colorectum & 12 & 9.88 \\
\hline Stomach & 9 & 7.68 \\
\hline Hepatocellular Carcinoma & 7 & 5.49 \\
\hline CNS (Brain+spinal cord) & 5 & 5.49 \\
\hline Periampullary & 5 & 4.40 \\
\hline Esophagus & 4 & 4.40 \\
\hline Prostate & 4 & 4.40 \\
\hline Oral cavity & 4 & 4.40 \\
\hline Skin+soft tissue & 4 & 73.60 \\
\hline 10 commonest & 67 & 26.40 \\
\hline Others & 24 & 100.00 \\
\hline Total & 91 & \\
\hline
\end{tabular}


It is evident from Table 7 that the 10 commonest causes of deaths were Gall bladder (14.29\%), Colorectum (13.17\%), stomach (9.88\%), Hepatocellular carcinoma (7.68\%), CNS (Brain+spinal cord) (5.49\%), Periampullary (5.49\%), Esophagus $(4.40 \%)$, Prostate $(4.40 \%)$, oral cavity $(4.40 \%)$ and skin+soft tissue $(4.40 \%)$.

\section{Time trend of Cancer admissions from 2010 to 2014.}

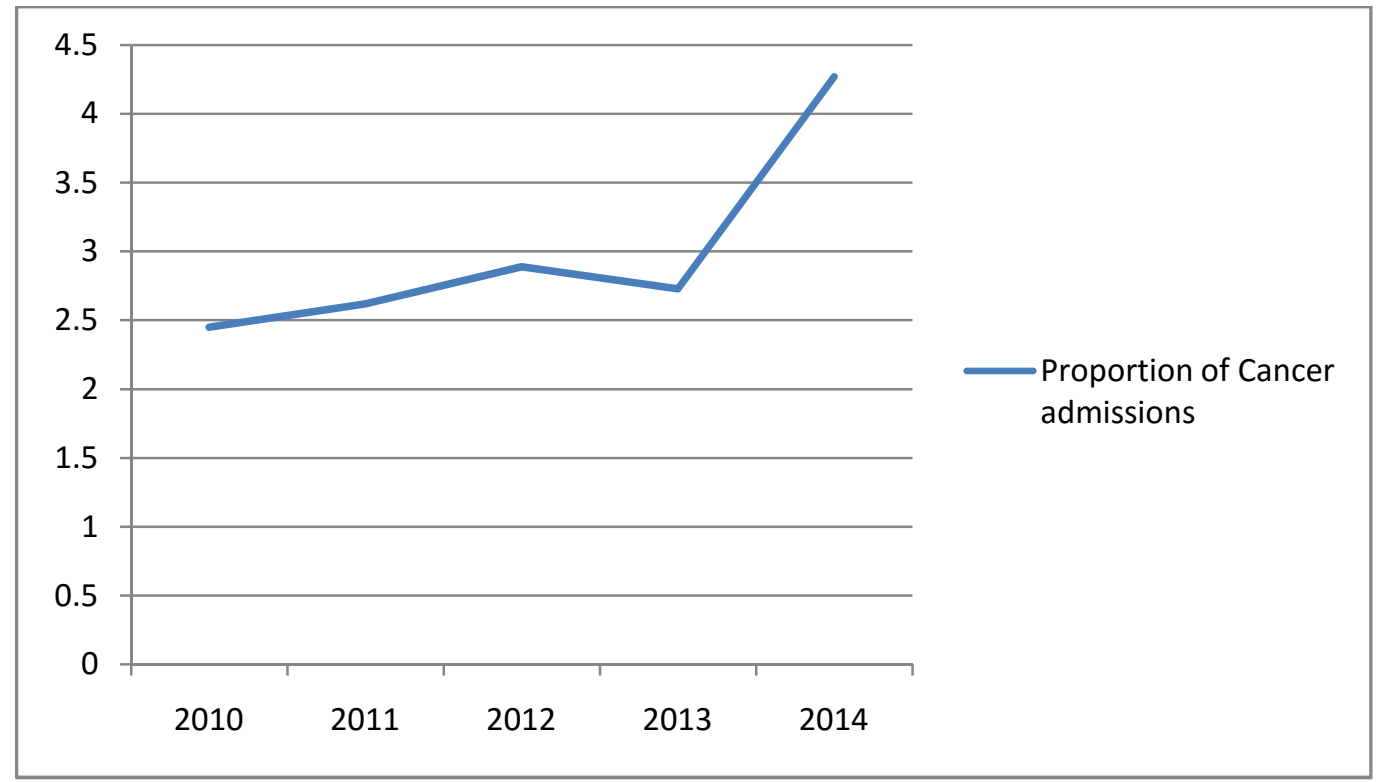

During 2010-2014, 39213 patients were admitted in surgical wards out of which 1186 patients were of Cancer which accounts for $3.02 \%$ of total admissions in surgical wards. The proportion of Cancer patients increased from $2.45 \%$ from 2010 to $4.27 \%$ in 2014.

\section{Discussion}

With the advent of the era of genetics, cancer has become one of the most researched diseases of the modern times and its etiopathogenesis is no more a mystery. Epidemiological studies are a major part of the research on cancer. The NCRP (National Cancer Registry Programme) with its pan-India network maintains a National database of cancer based on both population as well as hospital based registries and publishes the latest trends of cancer epidemiology. WHO (World Health Organization) publishes global as well as individual national data on cancer.

The incidence and mortality of various cancers are known to have age and gender predisposition. Various geographical areas too have different patterns of cancer distribution based on the genetic structure, sociocultural factors, levels of pollution, life-style and exposure to carcinogens of the local residents.

This variation can be as much as 100 folds in certain cases. A systematic study of the distribution of cancer incidence, prevalence and mortality helps in charting out a trend of cancer over time and formulating important preventive strategies e.g. long time observation of relation of smoking to Lung cancer led to a massive anti-smoking campaign and decline in incidence as well as mortality due to Lung cancer [14].

Incidence ${ }^{-}$In the present study, cancer accounted for $3.02 \%$ of the total admissions in surgical ward between 2010-2014. Globally,14 million new cases of cancer are diagnosed each year [3]. The age standardized cancer incidence rate is 182.3 per 100,000 population [7]. In India, the annual incidence of cancer in India is 10.15 lakhs. The age standardized incidence rate is 94.0 per 100,000 population [8,9]. The proportion of cancer patients in present study is high because it is a Hospitalbased study and there is no cancer hospital in the Vindhya region, hence all Cancer patients seek initial consultation in S.S. Medical College before being referred to specialized cancer hospitals. In order to estimate the prevalence of cancer in population, a population-based study is required.

Time trend of Cancer-In the present study, the proportion of cancer patients has increased significantly from $2.45 \%$ to $4.27 \%$ from 2010 to 2014 . Globally, 


\section{Research Article}

while cancer rates are decreasing in the western world, they are increasing in less developed and economically transitioning countries, including Eastern Europe, because of adoption of unhealthy western lifestyles such as smoking and physical inactivity and consumption of calorie-dense food. cancers once known as diseases of industrialized countries e.g. lung, colon, and breast cancers, now commonly occur in economically transitioning and less developed countries. Most of these countries are also disproportionately affected by cancers related to infectious agents e.g. cervix, liver, and stomach cancers which are potentially preventable. The share of cancer burden in less developed countries is projected to increase from $56 \%$ of the world total in 2008 to $>60 \%$ in 2030 because of increasing trends in cancer rates, expected increase in life expectancy and growth of population [10]. The incidence of cancer is expected to increase from 14 million to 22 million cases per year and Cancer mortality from 8.2 million to 13 million per year over next 2 decades [3]. In India, cancer is on rise. Among males, except the Mumbai PBCR, all HBCRs and PBCRs have noted an overall increase in the AAR (Age Adjusted Incidence Rates) for cancer with Bengalooru PBCR measuring the highest APC (Annual Percentage Change) of 2.69. Among the newer PBCRs, where statistics from 2003-2011 was calculated, except Mizoram and Sikkim states, all PBCRs and HBCRs saw an upward trend with Thiruvananthapuram PBCR recording the highest APC of 2.75. Among females, among the older PBCRs and HBCRs, except Delhi and Mumbai, the other ones showed a trend of increase in the overall incidence of cancer with Bengalooru PBCR recording an APC of 2.90. In the newer PBCRs, except the Sikkim state, Mizoram state, Imphal West Dist and Dibrugarh Dist registries which showed a downward trend, the other registries showed an increasing trend with Kamrup Urban Dist measuring $11.38 \%$ and Thiruvananthapuram PBCR an APC of $3.48 \%$. Findings in the current study are in coherence with National Data and is attributed to changing life-style and increasing pollution leading to accumulation of carcinogens and build-up of mutations as well as significant increase in the diagnosis of occult Cancers with the help of advanced diagnostic modalities.

Incidence according to age- Various cancers show various patterns of incidence in different age groups. The commonest relation with age is a progressive increase in incidence from near zero in childhood and adolescence to a high rate in old age e.g. Cancers of skin, lung, gastrointestinal and urinary tracts where annual incidence may be 1000 times greater above 75 than before 25. Some Cancers are typically found in pediatric population e.g. Retinoblastoma and Nephroblastoma. Many other cancers have bimodal or multimodal distribution e.g. Breast cancer and lymphomas. In the present study, $57.59 \%$ patients were of middle age group, $30.86 \%$ were of geriatric age group, $11.05 \%$ young adults and $0.50 \%$ of pediatric age. Globally, life-time risk of developing cancer before the age of 75 years is $18.5 \%$. (males $21.0 \%$, females $16.4 \%$ ) [7]. In India, life-time risk of developing cancer before the age of 75 years in India is $10.1 \%$ (males 10.2 $\%$, females $10.1 \%$ ) [8]. Most cases of Cancer are seen in the age group of 35-64 years. Among males of this age group, incidence varies from $55.2 \%$ in Chandigarh to $62.7 \%$ in Guwahati. Among females, it varies from $64.0 \%$ in Thiruvanathapuram to $74.3 \%$ in Dibrugarh. Among both the sexes, the figures vary from $60.3 \%$ in Chandigarh to $67.6 \%$ in Dibrugarh. The geriatric age group ( $65+$ years) is the second commonest to be affected by cancer. Among males, the incidence in this age group varies from $19.2 \%$ in Mumbai to $30.1 \%$ in Guwahati. Among females, it varies from $14.2 \%$ in Mumbai to $20.0 \%$ in Thiruvanathapuram. Among both genders, it varies from $16.9 \%$ in Mumbai to $24.5 \%$ in Guwahati. Next is the young adults (15-34 years) with incidence among males varying from $5.6 \%$ in Guwahati to $13.3 \%$ in Mumbai. Among females, it varies from $8.7 \%$ in Guwahati to $11.9 \%$ in Thiruvananthapuram. Among both genders, it varies from $6.8 \%$ in Guwahati to $12.5 \%$ in Mumbai. Pediatric cancers form rest of the bulk with incidence varying from $1.7 \%$ in Guwahati to $10.9 \%$ in Chandigarh among males, from $1.8 \%$ in Chennai to $6.4 \%$ in Chandigarh among females and from $1.8 \%$ in Guwahati to $8.9 \%$ in Chandigarh among both sexes [9]. Findings of the study are consistent with the National data as in almost all Cancer Registries, the middle aged people account for the highest number of Cancer cases, followed by geriatric age group, young adults and children. Epidemiological studies on Cancer give results close to accurate when the study is restricted to the middle age group individuals because pediatric and young adult groups have a relatively less incidence of Cancer and incidence of Cancer in geriatric age group is

often underestimated due to lack of universal diagnosis and reporting.

Incidence according to gender-In the present study, $50.25 \%$ patients were male, $49.75 \%$ were female. Globally, the age standardized cancer incidence rate is 205.4 for males and for females, it is 165.3 per 100,000 


\section{Research Article}

population [7]. In India, annual incidence of cancer is 4.77 lakh among males and 5.37 lakh among females. The age standardized incidence rate is 92.4 among males and among females, 97.4 per 100,000 population [8,9]. Males constitute $51.3 \%$ varying from $46.2 \%$ in Bengalooru to $59.2 \%$ in Guwahati and females constitute $48.7 \%$ varying from $40.8 \%$ in Guwahati to $53.8 \%$ in Bengalooru [9]. Findings of the present study are corroborating with the National data. It varies in respect to the Global data. Globally, incidence of Cancers of Breast and cervix which constitute the major bulk of female Cancers are on fall in most of the advanced nations because of effective preventive and treatment strategies while the cancers of lungs which are known to affect males more are still unanswered and are high on incidence making males suffer more. In India, Cancers of breast and Cervix both are on rise, making the females share a bigger burden of Cancer as compared to the global data.

Proportion according to religion- In the present study, 95.78\% patients were Hindus, $4.22 \%$ were Muslims. This reflects the normal demographic distribution of the local region. Rewa District has $95.93 \%$ Hindus and $3.61 \%$ Muslims [11].

Proportion according to socio-economic status-In the present study, $70.40 \%$ patients were BPL (below poverty line), rest $29.60 \%$ were APL (above poverty line). Compared with other common surgical diseases, the distribution of Cancer is more favored towards socio-economically affluent individuals due to the lifestyle hazards they are subjected to.

Proportion according to residence- In the present study, $67.2 \%$ patients were from rural areas, rest $32.80 \%$ were from urban areas. In Rewa, urban population is $16.73 \%$ [11]. Distribution of Cancer is more favored towards urban areas due to more exposure to risk factors.

Proportion according to addiction- $25.97 \%$ patients were addicted to tobacco, $18.63 \%$ were addicted to alcohol and tobacco both while $1.52 \%$ admitted to taking Alcohol alone. But the data does not conclude about any particular correlation of addiction and Cancer and to find out a definite correlation, a quantitative and temporal correlation between addiction and Cancer must be studied for a sufficiently long duration.

Proportion according to diet- $75.89 \%$ patients were vegetarians which reflects the common dietary pattern of the region. To find out a correlation of diet with cancer, a longer duration study with detailed history of exposure to particularly known Carcinogenic food agents must be done.

Proportion according to stage of presentation$18.38 \%$ of patients had proven distant metastasis at initial presentation. A detailed investigation and work up would have detected many covert metastasis.

Incidence according to site

\begin{tabular}{|c|c|c|c|c|c|c|c|c|c|c|c|}
\hline \multicolumn{4}{|c|}{ Present study } & \multicolumn{4}{|l|}{ In India $^{12}$} & \multicolumn{4}{|l|}{ Globally $^{7}$} \\
\hline \multicolumn{2}{|l|}{ Males } & \multicolumn{2}{|l|}{ Females } & \multicolumn{2}{|l|}{ Males } & \multicolumn{2}{|l|}{ Females } & \multicolumn{2}{|l|}{ Males } & \multicolumn{2}{|l|}{ Females } \\
\hline Site & $\%$ & Site & $\%$ & Site & $\%$ & Site & $\%$ & Site & $\%$ & Site & $\%$ \\
\hline Colorectal & 11.24 & Breast & 37.12 & Lungs & 11.3 & Breast & 27.0 & Lungs & 16.7 & Breast & 25.2 \\
\hline Prostate & 10.24 & Gall Bladde & 12.88 & Oral & 11.3 & Cervix & 22.9 & Prostate & 15.0 & Colorectal & 9.2 \\
\hline Penis & 10.24 & Colorectal & 7.28 & Stomach & 9.1 & Colorectal & 5.1 & Colorectal & 10.0 & Lungs & 8.8 \\
\hline Gall Bladder & 8.22 & Cervix & 6.61 & Colorectal & 7.7 & Ovary & 5.0 & Stomach & 8.5 & Cervix & 7.9 \\
\hline Stomach & 7.55 & Stomach & 5.59 & Pharynx & 6.6 & Oral & 4.3 & Liver & 7.5 & Uterus & 4.8 \\
\hline Skin & 7.05 & $\begin{array}{l}\text { Cholangi } \\
\text { o }\end{array}$ & 4.06 & $\begin{array}{l}\text { Esophag } \\
\text { us }\end{array}$ & 5.7 & Stomach & 3.7 & $\begin{array}{l}\text { UrinaryB } \\
\text { ladder }\end{array}$ & 4.4 & Stomach & 4.8 \\
\hline $\begin{array}{l}\text { Periampull } \\
\text { ary }\end{array}$ & 6.88 & Skin & 3.73 & Larynx & 4.8 & Lungs & 3.1 & $\begin{array}{l}\text { Esophag } \\
\text { us }\end{array}$ & 4.3 & Ovary & 3.6 \\
\hline $\begin{array}{l}\text { Oral } \\
\text { cavity }\end{array}$ & 6.88 & $\begin{array}{l}\text { Periamp } \\
\text { ullary }\end{array}$ & 3.22 & $\begin{array}{l}\text { Leukae } \\
\text { mia }\end{array}$ & 4.1 & Esophagus & 2.7 & Kidney & 2.9 & Thyroid & 3.5 \\
\hline $\begin{array}{l}\text { Hepatocell } \\
\text { ular }\end{array}$ & 4.53 & $\begin{array}{l}\text { Hepatoc } \\
\text { ellular }\end{array}$ & 3.22 & Prostate & 4.0 & Leukaemia & 2.4 & NHL & 2.9 & Liver & 3.4 \\
\hline $\begin{array}{l}\text { UrinaryB1 } \\
\text { adder }\end{array}$ & 4.03 & Ovary & 3.22 & Liver & 3.6 & Uterus & 2.3 & $\begin{array}{l}\text { Leukaem } \\
\text { ias }\end{array}$ & 2.7 & NHL & 2.5 \\
\hline
\end{tabular}




\section{Research Article}

Disparity with the National and the global data is because the present study has been conducted on patients admitted in Surgical ward and only surgically resectable or manageable patients were included in the study and many of the patients admitted opted for further treatment in Cancer hospitals after being diagnosed here. Patients of Cancer of cervix seek consultation in the Department of Gynecology and only those patients turn up in the Department of Surgery who have developed obstructive uropathy or malignant ascites, hence the low incidence of Cancer Cervix in the study. Similarly in case of males, oral cavity Cancers is the commonest throughout India but most of the cases seek consultation in the Department of ENT/Dentistry and only those cases with certain surgical complications report in the Department of Surgery.

Mortality-In the present study, cancer accounted for $3.64 \%$ of all deaths in the surgical ward and the case fatality rate of cancer was 7.67\%. Globally. 8.2 million people die of cancer each year [3]. The age standardized cancer mortality rate is 102.4 per 100,000 population [7]. In India, the annual mortality of cancer in India is 6.83 lakhs. The overall mortality rate is 64.5 per 100,000 population [8,9]. The reason behind high proportion of deaths of cancer patients in the present study is that it is a hospital-based study and there is no cancer hospital in the Vindhya region, hence all cancer patients seek initial consultation in the S.S. Medical College before being referred to specialized cancer hospitals. Many patients present in advanced stages and are unable to seek care in specialized cancer hospitals and die during palliative treatment in S.S. Medical College, Rewa. In order to estimate mortality rate of cancer in population, a population-based study is required.

Mortality according to age- In the present study, maximum deaths occurred in the middle age group (53.85\%) followed by geriatric age group $(35.16 \%)$ and young adults $(10.99 \%)$. There was no death among the pediatric patients. Globally, life-time risk of dying due to cancer before the age of 75 years is $10.4 \%$. Among males, it is $12.7 \%$ and among females, $8.4 \%$ [7]. In India, life-time risk of dying due to cancer before the age of 75 years in India is $7.1 \%$. Among males, it is $7.8 \%$ and among females, $6.5 \%$ [8]. The reason behind the relatively less proportion of total deaths attributed to cancer among the geriatric age group as compared to the global data is that a significant proportion of the deaths in this group remains uninvestigated and are attributed to non-malignant causes, due to lack of universal autopsy and mortality reporting system. A correct picture can be obtained if all patients in this age group are cared after properly and are diagnosed thoroughly and properly for their diseases and all deaths are subjected to autopsy to confirm the exact cause of death and a National databank of the same is maintained as is done in developed nations.

Mortality according to gender- In the present study, $61.54 \%$ of deaths occurred among male patients and $38.46 \%$ among female patients. Globally, the age standardised cancer mortality rate for males is 126.3 and for females, 82.9 per 100,000 population. In India, the annual mortality rate of cancer in India is 3.57 lakh among males and 3.26 lakh among females. The overall mortality among males is 69.7 and among females, 60.2 per 100,000 [8,9].

Mortality according to site

\begin{tabular}{|c|c|c|c|c|c|c|c|c|c|c|c|}
\hline \multicolumn{4}{|l|}{ Present study } & \multicolumn{4}{|l|}{ In India ${ }^{12}$} & \multicolumn{4}{|l|}{ Globally $^{7}$} \\
\hline \multicolumn{2}{|l|}{ Males } & \multicolumn{2}{|l|}{ Females } & \multicolumn{2}{|l|}{ Males } & \multicolumn{2}{|l|}{ Females } & \multicolumn{2}{|l|}{ Males } & \multicolumn{2}{|l|}{ Females } \\
\hline Site & $\%$ & Site & $\%$ & Site & $\%$ & \begin{tabular}{|l|} 
Site \\
\end{tabular} & $\%$ & Site & $\%$ & Site & $\%$ \\
\hline Stomach & 12.49 & $\begin{array}{l}\text { Gall } \\
\text { Bladder }\end{array}$ & 20.00 & Lung & 13.7 & Breast & 21.5 & Lung & 23.6 & Breast & 14.7 \\
\hline Gall Bladder & 10.70 & Colorectal & 17.14 & Stomach & 11.4 & Cervix & 20.7 & Liver & 11.2 & Lung & 13.8 \\
\hline Colorectal & 10.70 & Cervix & 8.57 & Oral & 10.2 & Colorectal & 6.4 & Stomach & 10.1 & Colorectal & 9.0 \\
\hline Prostate & 7.14 & Thyroid & 8.57 & Colorectal & 7.8 & Ovary & 6.0 & Colorectal & 8.0 & Cervix & 7.5 \\
\hline Periampullary & 7.14 & $\begin{array}{l}\text { Hepatocellula } \\
\mathrm{r}\end{array}$ & 8.57 & Pharynx & 7.6 & Stomach & 5.6 & Prostate & 6.6 & Stomach & 7.2 \\
\hline Hepatocellular & 7.14 & Stomach & 5.71 & Esophagus & 7.1 & Oral & 4.8 & Esophagus & 6.0 & Liver & 6.3 \\
\hline Esophagus & 5.36 & Oral & 5.71 & Liver & 4.7 & Lungs & 4.6 & Leukemia & 3.3 & Ovary & 4.3 \\
\hline $\mathrm{CNS}$ & 5.36 & $\mathrm{CNS}$ & 5.71 & Leukemia & 4.5 & $\begin{array}{l}\text { Esophag } \\
\text { us } \\
\end{array}$ & 4.1 & $\begin{array}{l}\text { Urinary } \\
\text { Bladder }\end{array}$ & 2.6 & NHL & 2.4 \\
\hline Skin & 5.36 & Cholangio & 5.71 & Larynx & 4.4 & Leukemia & 3.3 & NHL & 2.5 & Uterus & 2.1 \\
\hline Hematological & 5.36 & Periampullary & 2.86 & Prostate & 3.4 & Uterus & 1.5 & Kidney & 2.0 & Thyroid & 0.8 \\
\hline
\end{tabular}




\section{Research Article}

Absence of death due to breast Cancer in the present study can be explained by availability in the Institution of various treatment modalities for the management of breast Cancer including surgery, chemotherapy, radiotherapy and hormonal therapy which ensures a near complete treatment. Also many patients of Breast Cancer might have died due to other comorbid conditions in separate admissions and hence not included in the study.

\section{Conclusion}

This was a 5 year retrospective and prospective hospital based study. A longer duration prospective population based study with direct interviewing of patients regarding various relevant traits and following their management on a long-term basis would be an ideal and more comprehensive study. Nonetheless, this study helps in pointing out the prevalent trends in Cancer in the Vindhya region.

The battle against Cancer must be fought on many frontiers and a study to find out its determinants will act as a foot soldier and prepare the Cancer management team for greater challenges.

Conflict of interest: None declared.

Funding: Nil, Permission from IRB: Yes

\section{References}

1. World Cancer Factsheet, January 2014, IARC (International Agency for Research on Cancer),WHO.

2. Robbins Basic Pathology $8^{\text {th }}$ Edition Page 175.

3. Latest World Cancer Statistics, Press Release No. 223, 12 Dec. 2013, IARC (International Agency for Research on Cancer), WHO.

4. Cancer in India: Prevalence, Management and Outcome Prospects for Research Subrata Sinha Department of Biochemistry All India Institute of Medical Sciences New Delhi

5. Mallath MK, Taylor DG, Badwe RA, Rath GK, Shanta V, Pramesh CS et al. The growing burden of cancer in India: epidemiology and social context, The Lancet Oncology. May 2014:15 (6); e205 - e212.
6. Murthy NS, Mathew A. Cancer Epidemiology, Prevention \& Control. Current Science. February 2004: 86(4); 518-527.

7. GLOBOCAN 2013, World Fact Sheet (2013), Section of Cancer Information, International Agency for Research on Cancer, Lyon, France.

8. WHO (2003), World Cancer Report Ed. by Bernard W. Stewart and Paul Kleihues.

9. The National Cancer Registry Programme Consolidated Reports 2007-2011, ICMR (Indian Council of Medical Research).

10. Global Patterns of Cancer Incidence and Mortality Rates and Trends, Cancer Epidemiology Biomarkers \& Prevention, August2010,Ahmedin Jemal, Carol Sentalis.

11. The Census of India, 2011.

12. GLOBOCAN 2013, India Fact Sheet (2013), Section of Cancer Information, International Agency for Research on Cancer, Lyon, France

13. Kapoor VK, McMichaek AJ. Gallbladder Cancer: An 'Indian' disease. atl Med J India. 2003 JulAug;16(4):209-13.

14. Doll R, Fraumeni $\mathrm{J}$ et all. Trends in cancer incidence and mortality. Cancer surveys. Cold Spring Harbor Laboratory Press,New York.2014;Vol.19and 20,

15. Time trend of cancer incidence, 1982-2010, NCRP.

\section{How to cite this article?}

Shukla D, Patel VK, Chhari AS, Dubey CS, Garg RK, Singh AP, Bais PS, Gaharwar APS. Epidemiological profile of Cancer patients in Surgery ward of a tertiary teaching Hospital in the Vindhya region with special reference to high proportion of Carcinoma Gall Bladder. Int J surg Orthopedics 2015;1(2):32-41. doi: 10.17511/ijoso.2015.i2.03. 